\title{
The Importance of Invisible Local Industrial and Social Aspects on The Modern Architectural Project: Evaluating An Example of A Community Centre of The 1950s In Japan
}

\author{
Yasunori Kitao \\ Kyoto Women's University, 35, Kitahiyoshi-cho, Higashiyama-ku, Kyoto, Japan
}

Email: kitaoy@kyoto-wu.ac.jp

\section{ARTICLE INFORMATION}

Received:September 18, 2017

Revised: November 16, 2017

Accepted: December 15, 2017

Published online: January 01, 2018

Keywords:

Community Centre, Interior Development Projects-Post-war Period, Local Industries, Industrial Heritage

\begin{abstract}
The purpose of this paper is to evaluate an example of modern architecture in Shiogama Japan. The evaluation is made in terms of the effect of local industry and local community movements in relation to the transformation of Japanese society in the post-war period. As the ultimate purpose of the Modern Movement in Architecture is to benefit the common people, the current paper is focussed on the Community Centres that were built after Japan's defeat in the Second World War. At that time, the Japanese society changed rapidly from a military regime to a democratic one. The Community Centre that is dealt with, in this paper was built in the early 1950s, so one can expect to find some aspects of building a democratic society behind the actual building project. Further the invisible and the intangible value of this Community Centre has been discussed in the period when the Japanese government promoted interior resources development projects.

The purpose of this research is to understand some hidden historical values of the Community Centre, which represent not only the social phenomenon of that period, the architectural expression and technical aspects of the building but, also, the local industrial heritage. The paper also describes the importance of sustaining support for the local peoples' activities by conserving this Community Centre and, then, explains how the Municipality of Shiogama decided to renovate this historical piece of modern architecture. Now, the former Community Centre has been re-born as a Community Centre and a Museum of Art for a local painter.
\end{abstract}

\section{Introduction: The urpose and Background}

The purpose of this paper is to discuss the importance of the invisible and intangible aspects behind modern architectural works since the Second World War. These modern projects should be evaluated by the people for whom the architect had designed, the citizens who are still alive or, citizens who are able to write or say something about the project according to their experiences - all these becoming testimonies. However, it would not be easy for ordinary citizens to evaluate a piece of modern architecture scientificall, even though they have used the buildings in their daily lives, as most of them have not been trained in scientific methods. On the other hand, third party - scientific observers, do not have enough real experience of the particular project to figu e out these invisible "facts", because they are not necessarily the users.

As scientific methodology must be reliable and verifiable, it has been taken care to focus only on the formal features of the structure and, the philosophy of the architects, as being the visible "truth". Most of the invisible "facts" in terms of the social and industrial conditions, which led to the establishment of these modern architectural projects, have naturally disappeared or lost with the passing of time. As revisiting the past is impossible, nobody today is able to describe those important invisible "facts", which were known and experienced by the citizens who were the users in the past. What is to be stressed here is that there is an everwidening gap between the visible "truth" and the "invisible facts" which constitute the evidence for evaluating these projects objectively and, as time passes, these important invisible "facts" may disappear completely. Evidence of this widening gap can be clearly understood if we compare the gap in understanding of the 20th century projects with those of the pre-20th century period.

Although these "invisible facts" may be regarded as poetry, what we, the scientists, can do for modern projects is to understand and illustrate these "facts" on behalf of the users - as only scientists using empirical methods can. The adoption of this process may provide an important feature that the study of modern architecture lacks, and may help to 
narrow the gap between our perception of a building from the designers' point of view as the visible 'truth' and, the evaluation of that building from the users' point of view, as the actual but now invisible "facts". The efore, the role of today's scientists should be to investigate, formulate and, record the backgrounds to these projects - which are the invisible "facts", which are closer to the reality than the visible "truth" - in order to compile a frame of reference for future projects. This is important as these invisible "facts" would otherwise be forgotten. Putting a value on discovering these invisible "facts" in our time will be an important contribution to the social value of future building projects. Thus, our team decided to focus on an investigation of the social and industrial backgrounds, which are not visible today, but which gave birth to a project.

\section{The A chitectural Profession and Architecture In The 1950}

In 1950, the Japanese government constituted its building regulations, which are still used in the country. Thus, we understand that the period of the 1950s was the dawn of the architectural profession and of building regulations. At that time the Japanese Government was controlled by the General Headquarters of the Allied Powers and, was preparing for independence after the Second World War. The 1950s was the reconstruction period of Japanese society, the same as other countries at that time. As the result of the government's economic development policy, Japanese society entered an era of high-speed economic development in the 1960s. The decade of the 1950s was an important period when the foundations of current Japanese society were established.

The aim of the building regulations, known as "Kenchiku-kijyunhou", was to enhance the welfare of society by establishing new architectural projects. This idea can be recognized in Article No.1 of the Building Regulations, which requests architects and building engineers to work for the benefit of the general public. Actually the Japanese Federation of Architects and Building Engineers Association (JFABEA) has been working to instil professionalism in their members, and encouraging them to contribute to the development of local communities. This point was also discussed in the 2011 UIA Symposium in Tokyo. In the discussions, some ideas regarding the professionalism of the architect's contribution to the local society as a kind of modern movement have been shared. Thus, these building regulations indicate the modernization of the architectural profession.

Next, the professionalism and backgrounds of architectural projects in the 1950s in Japan have been discussed using an example. This paper aims to describe and evaluate the invisible aspects of a Community Centre that was designed and built in the 1950s when the modernization of professionalism was first adopted by building engineers and architects. The said Community Centre was built in Japan in the 1950s and, was designed by the Municipality of Shiogama. This example has been used to discuss the modernization of professionalism and modern projects, in terms of their social and industrial aspects. It is hoped that this point of view will contribute to understanding some features of modern architecture, narrowing the gap between the 'facts' and the 'truth'.

\section{The Const uction of The Communit Centre}

The Community Centre, discussed in this paper is an example of Modern Architecture, in Shiogama city, Miyagi Prefecture, Japan. It was constructed at the request of the Ministry of Education, which issued a notice asking each municipality to build a Community Centre for the purpose of developing cultural activities among the citizens. These Community Centres were intended to function as libraries, exhibition halls, social meeting places, vocational training centres and, so on, with the aim of building a democratic society from the local communities. The government recommended that the local municipalities should establish, maintain, and use these community centres according to the needs and will of the local people, using the budget of each municipality, because the Community Centre projects presented an opportunity to fulfil the democratic process in each local community. (National Institute for Educational Policy Research of Japan, 2006, "The Basic Documents", p.11). We understand that each community centre was a symbol of the democratic movement enforced by the government after the war.

Accordingly, in line with the government's policy, the municipality of Shiogama set up a building committee for the community centre consisting of sixty citizens selected by the Mayor and, this committee established an initial community centre in a Christian church in the city. This was the starting point of the current community centre. The building committee officiall requested the Mayor to build a new Community Centre and, then the municipality decided to prepare a budget for its construction in April 1950. Construction started in July 1950 and the new building was completed in January 1951. (The Community Centre of Shiogama, 1958, "In The Handbook of the Community Centre", p.11). From this historical data it was affirme that this public project was carried out in the spirit of initiating the new building regulations, for the benefit of societ .

The efore, this building represents the social welfare policy of the Japanese government. Actually, in 1952 and 
1954, the Miyagi Prefecture and the Japanese Government presented awards to this Community Centre because of the high standards under which it was being operated. In fact, so many people participated in numerous activities that the local people soon needed to build an extension. The people of the city donated the money and, the extension project was completed in July 1957 (The Community Centre of Shiogama, 1958, "In The Handbook of the Community Centre”, p.11) (Fig.1 \& Fig. 2). According to an interview with a representative of the municipality, the extension building started to be used after 1958. The total number of users for the year 1954 was 165,000 (The Community Centre of Shiogama, 1958, "In The Handbook of the Community Centre", p.9). This number is around four times as big as the population of the city, as the total population of Shiogama in the 1950s was around 45,000 (The Compilation Committee of Shiogama's History, 1986, "The History of Shiogama City II”, p.736). From this it can be inferred that the Community Centre was very popular amongst the local people.

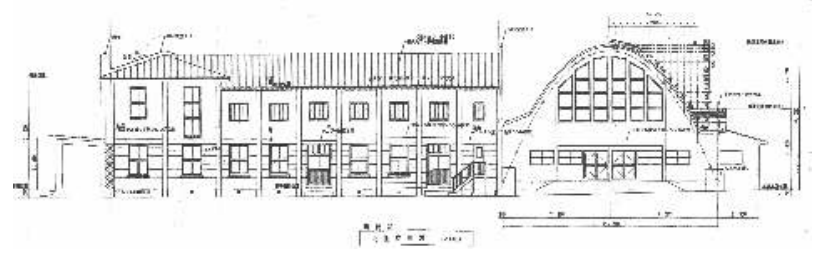

Figure 1. An Elevation of the Community Centre (Source: Municipality of Shiogama).

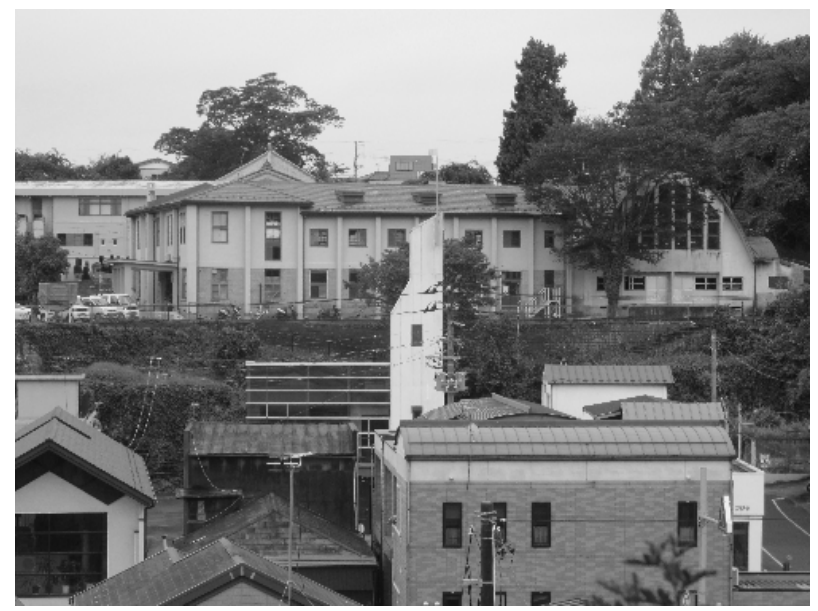

Figure 2. The Community ent e (Source: Author, 2012).

\section{Architectural Features of The Communit Centre}

The community centre consists of two parts. One part, which is the main building, houses the administration office a kitchen, a reading room, meeting rooms and so on. The other part has a community hall, which was extended in 1957 (The Community Centre of Shiogama, 1958, "In The Handbook of the Community Centre", p.8). The e was a public library in the main building. The public hall was used for a variety of purposes such as a dance hall, a theatre, a cinema and so on. The hall also provided a venue for public elections. (The Municipality of Shiogama, n.d., "An Architectural Feature"). The building surrounds a courtyard, and there is a terrace between the inner corridor and the courtyard. The main building is " $\mathrm{L}$ " shaped, and the extension of the public hall created the courtyard (Fig.3).

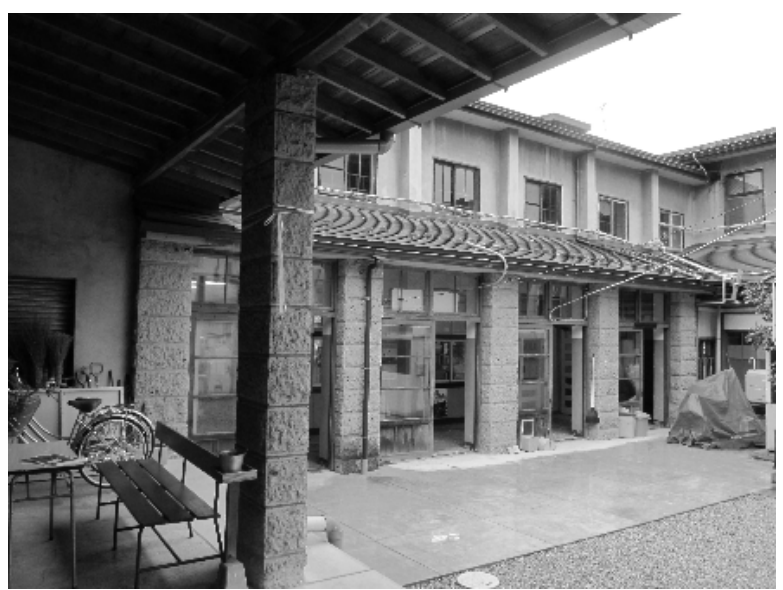

Figure 3. The Court Yard (Source: Author, 2012).

One of the most important features of this building is the main structure of the public hall. The elevation of the public hall is in the shape of a catenary curve, which shows the modernity of the building. The height of the building to top of the catenary structure is $9.7 \mathrm{~m}$. Thiscatenary shape was formed of laminated wood (Fig. 4). This structure was called the "Mokotuamiita-Kozo" in Japanese language, denoting the weaved-wood laminar structure (The Community Magazine of Shiogama, 2012, Fureaiesupu Shiogama”). This vertical section is practical for many purposes.

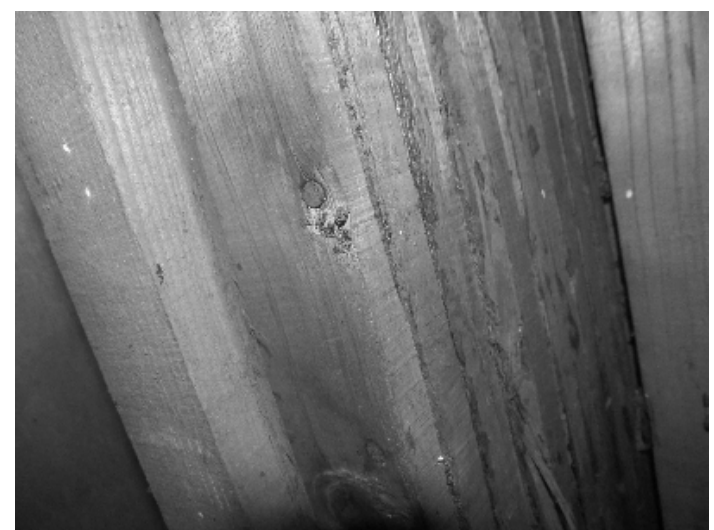

Figure 4. The Plywood Structure for the Public Hall (Source: Author, 2012). 
In the Japanese architectural history of the catenary structure; another example is of Yoyogi Stadium by Kenzo Tange. Compared to this excellent work, the public hall is an earlier example of a catenary structure in modern architecture. This structure gave a lofty vertical space to the interior of the public hall, which is presumed to have represented the church building which was adopted as the initial community centre (Fig. 5).

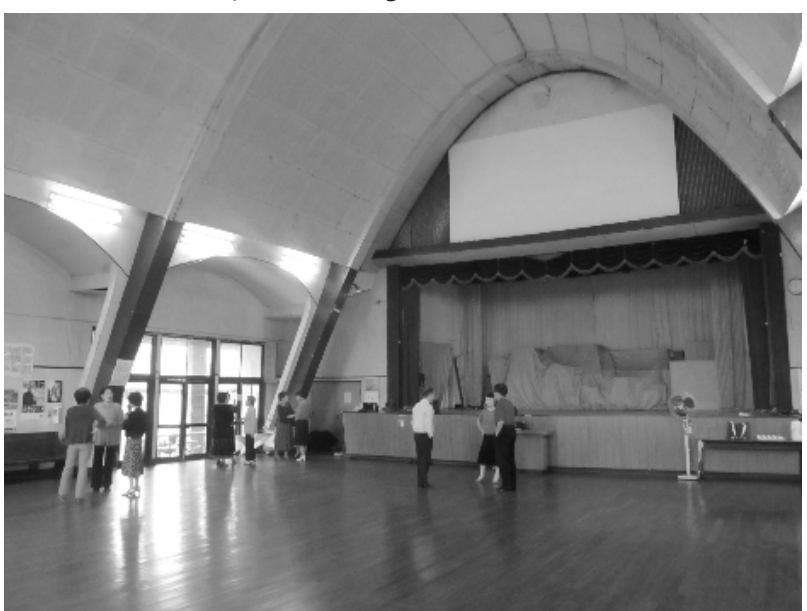

Figure 5. The ublic Hall (Source: Author, 2012).

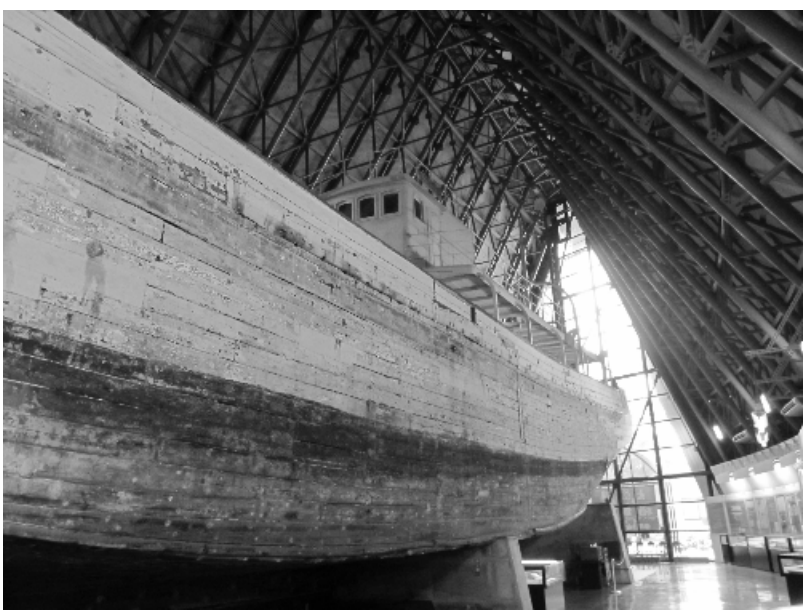

Figure 6. The Wooden Fishing Boat, Called "Daigo Fukuryu Maru (第五福龍丸) “(1946), Yumenoshima, Tokyo, Japan (Source: Author, 2017).

The main industries of the city were ship building and woodworking, so the architects of the community centre intended to use local technology for the community's central architectural features. Here, it is important to explain wooden ship building methods in mid-20th century in Japan. After the Second World War, the GHQ (General Headquarters, the Supreme Commander for the Allied Powers) ruled Japan. During the occupied period (19451951), it was impossible for the Japanese fishermen to catch any fish in the oceans. They just fished near the seacoast. After recovering independence, this restriction was released, and the fishermen were able to fish in the ocean, so they needed bigger fishing boats, which were made of iron. So, the ship building method was changed from wood to iron. Until the mid-20th century, Japanese ship builders used traditional Japanese ship building methods. In particular, the ship building technicians and carpenters used a traditional technique called the 'steam bending method' in order to build wooden boats ${ }^{1}$. (Fig.6).

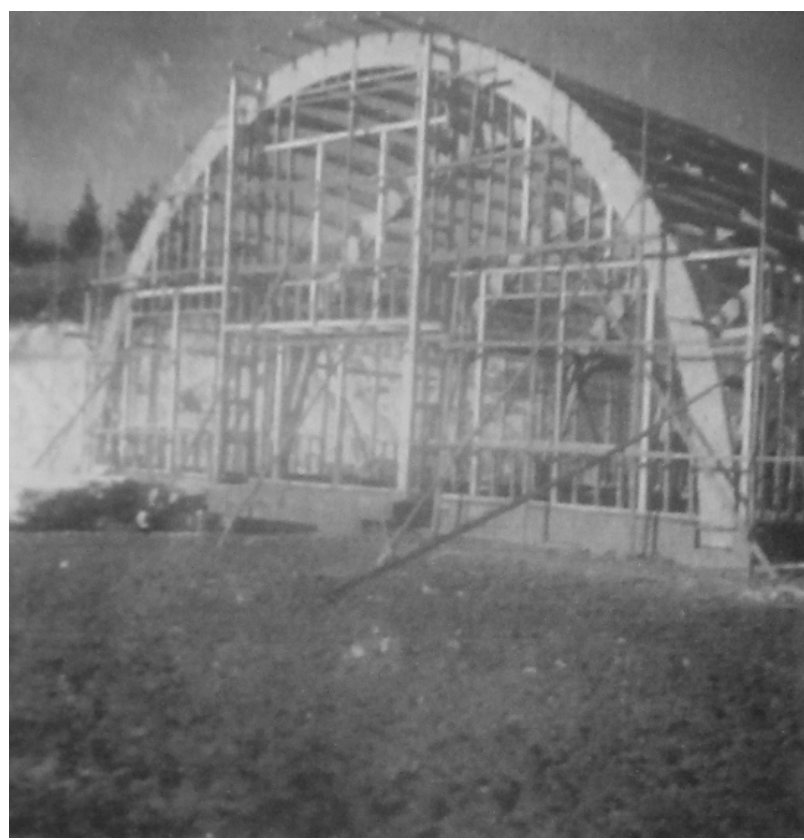

Figure 7. The gymnasium in Shiogama in the 1950s (Source: Mitsuo Kobayash)[小林光男]. This Photo is exhibited in the Shiogama Sugimura Jun Museum of Art.

The city of Shiogama was an important fishe y port in the north part of the Japanese main island, so there were shipyards and timber factories in which fishing boats were built and repaired. Thus, the architects of this community

${ }^{1}$ Regarding Japanese wooden boat building in the mid-20th century, there is a wooden fishing boat, built in 1946, in a museum in Tokyo. The name of the boat is "Daigo Fukuryu Maru" (Fig.6). On March 1st, 1954, the U.S.A conducted an atomic bomb test at Bikini Atoll in the Pacific Ocean. The crew of this boat were exposed to radioactive contamination. This incident drew 30 million Japanese to form a public movement against nuclear testing and nuclear weapons. As a result of this citizen's movement this abandoned wooden ship was found in a garbage dump in Tokyo, and conserved and exhibited in 1976, for the sake of eternal peace and to show the history of the fishing industry.(Retrieved October 20, 2017, from http://d5f.org/ en/index.php). There is a point worth discussing here; After the Second World War, wooden boat technology, using laminated woods was imported from the U.S.A, for military purposes. However, this technological idea from U.S.A which could have replaced traditional shipbuilding methods was discarded. The use of laminated woods for constructing fishing boats could have become the shipbuilding method during the 1960s, until boats constructed of iron became popular. 
centre applied this shipbuilding method for the main structure of the central hall, and then the laminated timber structure appeared as an advanced building method. This structure was used for a gymnasium in the city in the same period (Fig.7). Thus, it can be confirmed that the municipality/architects intended to sustain the local wooden shipbuilding industry by incorporating it into the local building industry, because shipbuilding methods and materials had changed during the 1950s.

The second feature of this building is seen in the material covering the walls of the building. The architect used Shiogama-ishi stone for cladding the walls of the main building and on the pillars of the public hall. Shiogama was famous for this stone. Shiogama-ishi stone is a kind of pumice tuff which is easy to shape, and several companies were running mining businesses in the city. This stone was very useful for agricultural warehouses, and development projects in the northern part of Japan needed this stone for their building projects. The idea of employing Shiogama Stone for the community centre was suggested by the Mayor, Mr. Sakurai (The Community Centre of Shiogama, 1958, "In The andbook of the Community Centre", p.10).

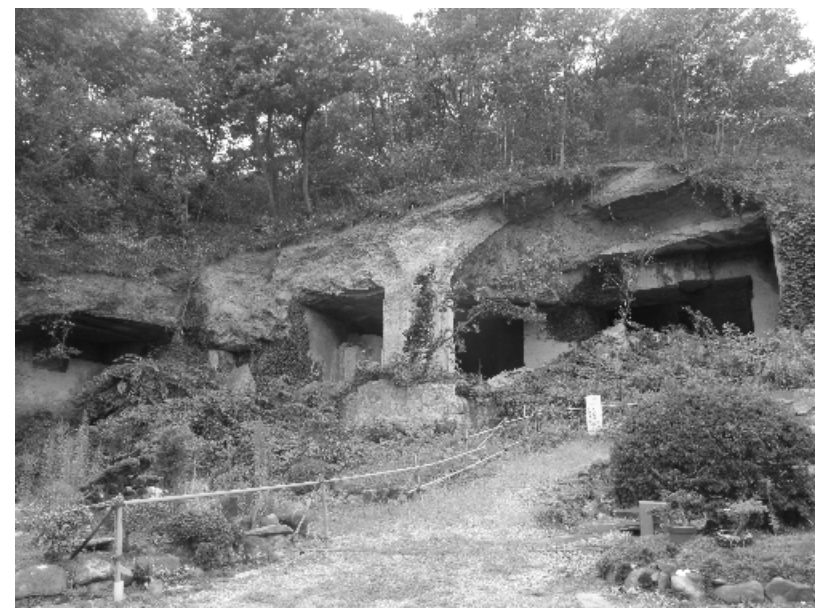

Figure 8. The remains of a quarry in Shiogama (Source: Author, 2012).

The e used to be several quarries sites in the city. (The Board of Education of Municipality of Shiogama, 2012, "Handbook of the Education", pp. 44-45) (Fig. 8). A stone industry company was operating until 2006. It stopped mining Shiogama-ish Stone (Fig. 9), but several traces of these stone quarries can be seen (one site is next to the city hall).

The stone industry was most active before 1950s. The stone was used for the main structure of buildings, but after the new building regulations were introduced, the use of stone for the structure of a building became a difficul issue from a technical point of view. (Using reinforced concrete was recommended and promoted by the government at that time.) The efore the city's stone industry decided to change its business style. Many stone companies started construction businesses for civil engineering. (Seiichiro W., 2012) It is assumed that one reason why the mayor requested the architects to use Shiogama-ish stone was to find a new way for the building industry to use this local material, while conforming to the new building regulations.

The efore, the architects decided to use this material for the surface of the building. Cladding the building with Shiogama-ishi stone was intended as a way to support and activate the local stone industry. This is yet another reason for evaluating this community centre as an example of locally orientated modern architecture. The community centre could have been a technical innovation project for the local industries.

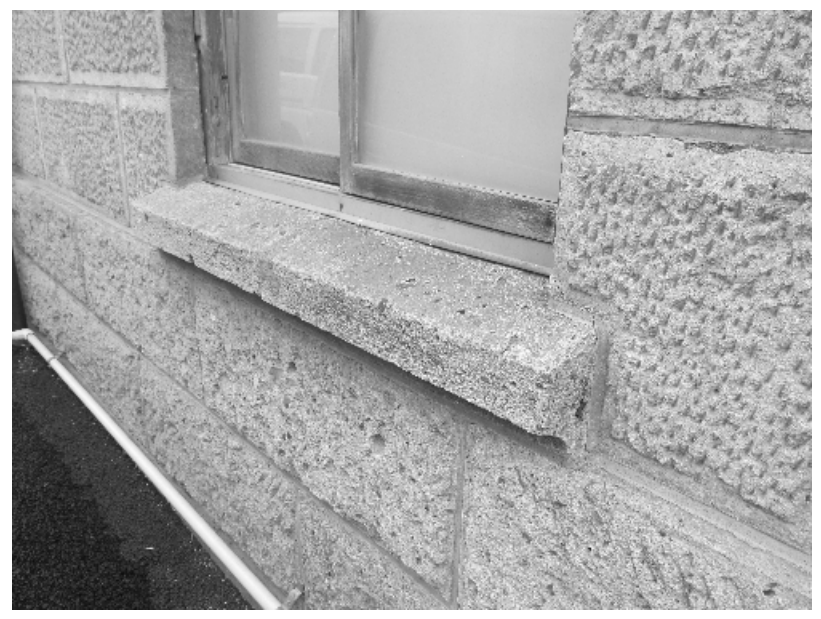

Figure 9. A Photo of the Shiogama-ishi Stone (Source: Author, 2012).

\section{The lywood Industry in Japan}

According to the research by Dr. Yotusi (1976), the plywood industry in Japan started from the 1930s in Akita Prefecture, and formed a certain production system in the 1960s in local areas. In 1958 there was an experimental building project using plywood in Noshiro (Akita Prefecture), but this project was not completed. (The Union of Plywood Industry of Japan, 2008, "The Report of Durability", pp. 86-87)

The oldest example of plywood-structured architecture was a forestry memorial building in Tokyo (1951). This building employed plywood for the main structure, but its plywood structure was not exposed to the user. The body of the building was box shaped and capped by a pitched roof. However, the architect's use of plywood as the formal feature of the structure was not apparent in the completed design. This plywood structure was used instead of the usual 
wooden beam of typical wooden architecture (The Union of Plywood Industry of Japan. n.d., "The History of Important Plywood" \& Yotusi, R., 1976). A structural member of this building has been preserved by the Forestry and Forest Products Research Institute (FFPRI). (The Union of Plywood Industry of Japan, n.d. "The History of Important Plywood Buildings"). Other examples of plywood-structured buildings in the 1950s were warehouses and gymnasiums, but these examples did not reveal this structural feature as an architectural expression (The Union of Plywood Industry of Japan, 2008, "The Report of Durability", pp. 10-12). Comparing these examples with the community centre with its uniquely shaped plywood beams, we are able to say that the structural design of the public hall was an advanced technology in Japan in the 1950s.

Actually, from technological development point of view, the plywood industry was in its early stages in the 1950 s, and actually matured in the 1960s, it could be understood that the technical development employed by the architects of the community centre makes it quite an advanced development project. So, the structure of the public hall in the community centre was an early example of plywood structure in Japan, using what was advanced technology, aiming for the activation of the local industry of Shiogama.

On the other hand, the wood industry was very important politically in Shiogama city around 1950, because many of the members of the municipal assembly got their votes from the people of the wood industry (The Compilation Committee of Shiogama's History, 1986, "The History of Shiogama City II", p.638). Considering the relation of the wood industry in Shiogama to the local economy, building up the industry was a high priority for the municipality. From this, it highlights that the architect invented a new structural system for the community centre, in order to activate the city's timber industry. Seeing the plywood structural members of the community centre, we are able to affir that this project is a kind of neo-realism architecture, using local materials and advanced plywood technology, which were related to the main local industries of the city in the 1950s.

\section{The Community Cent e and The Loca Community}

In the reconstruction period of Japan after the Second World War, the city of Shiogama underwent very rapid urbanization, because people who were suffering from a shortage of food, came to live in the city just because of its thriving fishing industry. In terms of food supply, this city was very attractive to the common people, and so many new inhabitants immigrated to the city from neighbouring prefectures, Seiichiro (2012). An important feature of the city is its early and swift urbanization even before the rapid economic development period had begun. After the Second World War an important political aspect of the city can be seen. The mayor who started the community centre was the first mayor to be elected by a direct vote by the citizens of the city. This was the first example of a mayoral election among the Japanese municipalities. Before the Public Offic Election Law was passed (1950), the mayor of the municipalities was appointed by the Home Offic of the Japanese Imperial Government (TheJapanese Government abolished the Home Offic in 1947). In 1946 the Home Office requested the city council to recommend a candidate for the mayor of the city to the Home Offic using the old governmental system and then the city council decided to carry out a public election in order to recommend the mayor to the Home Offic

This experience was the first example in Japan of a vote by the citizens for a mayor (At that time, the movement for democracy appeared, and the city council realized that it would be difficul if not impossible to recommend the mayor by using the old ruling system). Before a law defining the direct election of the mayor was formally instituted, this election method was used by neighbouring municipalities, and spread throughout the municipalities in Japan.

As the result of the first civil election in the city of Shiogama, Mr Sakurai was selected as the mayor (The Compilation Committee of Shiogama's History, 1986, "The History of Shiogama City II”, pp. 680-683). The advanced democratic and political aspects of the city in Japanese society are seen behind the building of the community centre. When all these invisible "facts" are revealed, it can be understood the Shiogama people's high consciousness of political and social matters. Behind the community centre building project, we are able to understand the democratic activities and the orientation of the citizens and the municipality. On the other hand the financial condition of the municipality was not healthy. The budget of the municipality had almost run out, just like other municipalities in Japan. This financial collapse took place in 1952 and the community centre project was carried out under these tight financial circumstances. In order to make money for the community centre project, the municipality sold reclaimed land that had been reserved for future industrial projects (Seiichiro W., 2012). Thus we can understand that the community centre was designed with consideration for a limited and minimal budget. The background to this process demonstrates to us that the will of the mayor, representing the voice of the citizens and expectations of the general public for the community centre, was very strong.

According to the record of the utilization of this community centre, the public used this building for classes, debates, exhibitions, exercise activities, elections, social 
meetings and so on. Performing groups, a folk dance club, an English club, a wind orchestra, a chorus group and a reading-circle used this community centre daily (Th Community Centre of Shiogama, 1958, "In The Handbook of the Community Centre", pp. 9-12). Not only these citizens' groups, but also chorus groups from universities and traditional music groups from other areas performed there. A traditional folk song program was carried out by the staff of the municipality of the city. The audiences came not only from the city, but also from the neighbouring municipalities. The citizens' painting group has been working for the annual painting exhibition since the 1950s. (Seiichiro W., 2012) Thesekinds of cultural or social activities were promoted in the radio broadcasts of the municipality of Shiogama by NHK, the national broadcasting company of Japan (Nihon Hoso Kyokai). The municipality distributed a community journal on the activities of the community centre twice a month. Th total number of copies of the journal printed in the 1950s was 11,500 (The Community Centre of Shiogama, 1958, "In Th Handbook of the Community Centre", pp. 9-12). At that time the number of families living in the city was 12,134 (Th Board of Education of Municipality of Shiogama, 1975, "Th History of Shiogama", p.57), so we can see from this that the municipality was running the community centre by keeping in close touch with the general public.

\section{The Community Cent e in Urban Development}

The community centre is located on top of a small hill in the old centre of the city. The site was adjacent to the historic centre. This site was used for the magistrate's office of the domain of Sendai before the Meiji Restoration (this took place in the middle of 19th Century). After the westernization of Japanese society at the end of 19th century, the site was used for a primary school (Department of Port, the Municipality of Shiogama, 2003, "News of the Venice"). The Christian church in which the city's first community centre was started was next to the current community centre. Shiogama was an important port city for development projects in the northern part of the Japanese Islands. Actually, Shiogama bay was reclaimed and the old centre of the city was formed before the westernization era. (The History of Port City Shiogama and Shiogama Shrine, 2003, "In the Second Report, p.35) Due to the development projects of the port of Shiogama, the population of the city increased from 4,000 (at the end of 19th century) to 23,000 in 1930. The railway connected with the port and the city carried many kinds of goods and articles from the city to the northern part of the country. From the middle of the 1920 s, the urbanized area was extended according to the reclamation projects. (The History of Port City Shiogama and Shiogama Shrine, 2003, "In the Second Report, p.39)

After the Second World War, Shiogama Port was an important international shipping harbour, and extensive port development work was carried out. Thecommunity centre was built during this period. The mayor and municipality made this plan in order to establish their city as an international port city in the 1950s (The Compilation Committee of Shiogama's History, 1986, "The History of Shiogama City II", p.736). Fishing boats for pelagic fishing used the port frequently in this period (NPO-Minatoshiogama, 2004, "A History of Port", p. 41). We can understand that in the 1950 s this was a thriving urban area. On the other hand, the urban development projects were introduced not only into the bay area, but also the inland area after the 1950s, and as a result of the large urban development project the urban area of the city was extended and divided into the waterfront area and the inland area. These inland suburban development projects brought many kinds of public facilities to the area (The History of Port City Shiogama and Shiogama Shrine, 2003, "In the Second Report, pp. 42-43). As a result the basic structure of the city was completely changed and the population balance of the city was transformed as well.

As the result of this urban explosion, public facilities, including community centres, were developed in the suburban area, and the matter of whether the municipality should maintain this building as a community centre or not with consideration for the other public facilities was discussed by the city council. As a result of the discussion and research on the safety of the structure, the municipality decided to continue to use the building as a community centre, because its location was very close to the old centre, so that the local people, who had been using the facility, could continue to use it. It turned out on inspection that the main structure was strong enough to withstand a possible earthquake. Thes two points became the reasons to maintain this architectural work as a community centre ${ }^{2}$. (Seiichiro W., 2012)

\section{Renovation Project of The Communit Centre}

Around 2012, the municipality of Shiogama was looking for a chance to renovate the community centre. The author conducted a research project in order to evaluate this work in September 2012. He wrote a report on the building and submitted this report to the municipality at the end of January 2013. As soon as the report was accepted by the municipality, the city council of Shiogama discussed the renovation project and decided to make a budget for the renovation project.

${ }^{2}$ The author conducted the research project on the community centre in Shiogama in November 2012 and October 2017. 


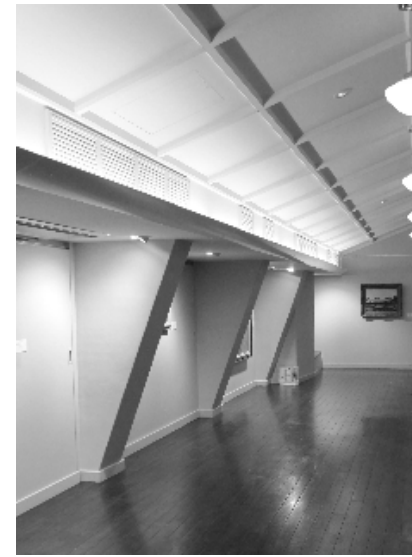

(a)

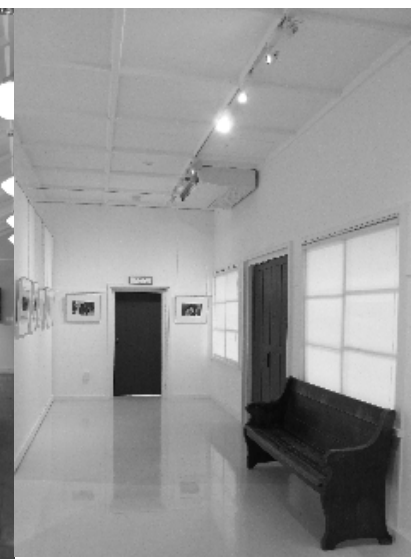

(b)
Figure 10. The Exhibition Rooms of the Museum of Art (Source: Author,2017) Note: The ideal form of the gallery as a white cube is seen in the interior spaces of the art museum.

In May 2013, the guideline of the renovation project was opened to the public and open competition to win the contract for the renovation work started. In June 2013, Tohoku Institute of Technology conducted research and in October 2013 this community centre was designated as a historical monument of the city. The renovation work was started in November 2013, and completed in November 2014. In this renovation project, a new art museum was planned together with the community centre. The building part, which was constructed in 1952 was transformed into the Shiogama Sugimura Jun Museum of Art (Fig.10), and the central hall, built in 1957, was renovated as the generalpurpose space it used to be (Fig.11). The guideline of the renovation project indicated that the important point was to preserve the atmosphere of the original space.

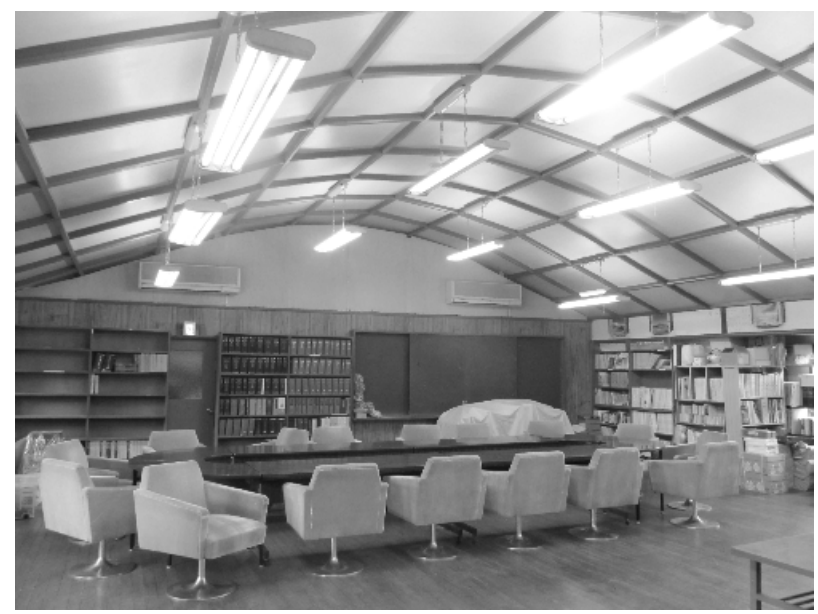

Figure 11. The Local Library in the Community Centre, Before the Renovation, 2012 Note: This room is used for the exhibition room for the local painter (see fig, 10
After the renovation work was completed, the complex of the Community Centre and Art Museum accepted a new private organizer, who was willing to do something for the memories of the local people, because this Community Centre still has a role in the daily lives of the local people. Today this complex is used not only by the elder people but also by young people for the sake of maintaining and creating common memories of the local area.

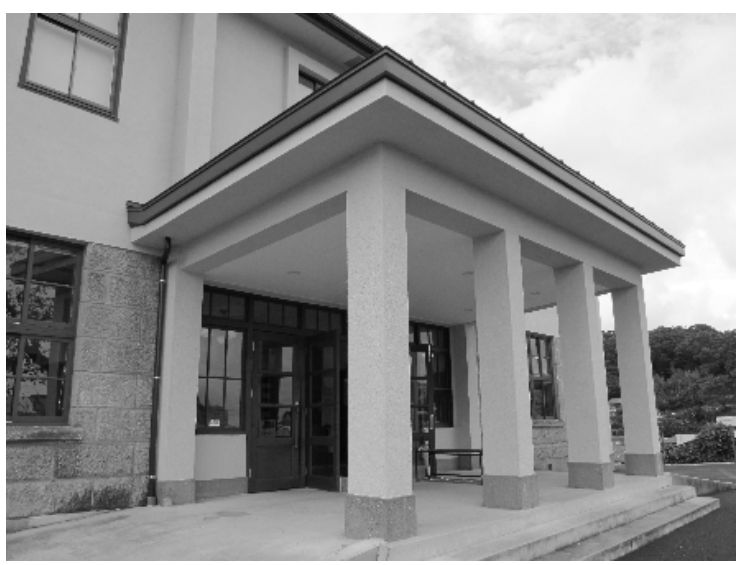

Figure 12. The Main Entrance Building of the Community Centre (Source: Author, 2017)

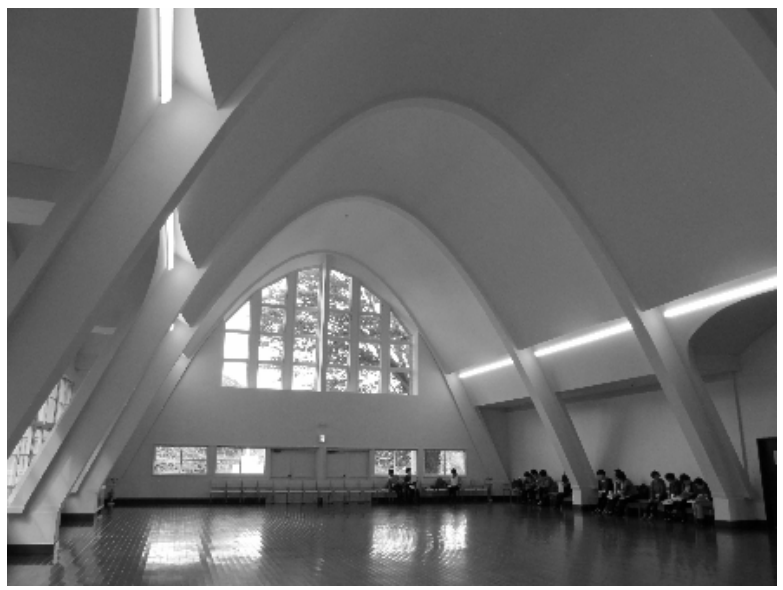

Figure 13. The Centre Hall of the Community Centre (Source: Author, 2017)

\section{In Between "Truth" and "Facts"}

As we have discussed only the invisible aspects of an example of modern architecture in the 1950s in Japan, which is still used frequently by the local people, we are still not in a position to recognize monumental or spectacular aspects of the architecture, but through the stories behind the planning, construction and running phase, we are able to see the authentic purpose of this piece of modern architecture. In other words, this can be described as architecture not 
only for the people, by the people, but also for the local society and its industries. This example illustrates for us the historical formation of a democratic and industrial Japanese society in a local city in the twentieth century. It is necessary to investigate the invisible "facts" in order to understand this kind of community architecture, which is a unique type of building in the history of architecture, demanded by the ordinary people, supported by the innovation of the local technology, and showing the needs of 20th century society.

Actually, this kind of building project teaches us the importance of investigating the background to the original project, which is closer to the invisible "facts", and farther from the visible "truth" as we experience it today, because the local people, some of whom are still alive, have left documents or spoken about this modern project from their actual memories. So from their contribution, we intend to extract what the local people have left behind or still remember. Particularly by using this example, we are able to understand, from a technical point of view, the significance of modern architecture, which can be found both in social studies and architectural studies. This argumentation is linked with the Nara Document as well (TheNara Document on Authenticity, 1994, "Nara Conference"). These points, which can be shared by the local people, are irreplaceable aspects of modern projects. The efore, when evaluating an example of architectural heritage, we should seek to understand the diffe ence between the invisible "truth" and the visible "facts" and things on a local level lying between "truth" and "facts" by seeking out all the historical records and first-hand reports available to us. If we believe in the dream of modernism; democracy and humanity, we cannot but accept this authentic spirit of the 20th century.

\section{Acknowledgements}

In order to carry out the research project on the community centre, the author was supported by the Municipality of Shiogama, The Union of Plywood Industry Japan and, the Japan Federation of Architects and Building Engineer's Association. This work was supported by JSPS KAKENHI Grant Number 16H02386.

\section{References}

[1] Department of Port, the Municipality of Shiogama. (2003). News of the Venice Project of Shiogama No.3 [Shiogama Venizia Keikaku News No.3, in Japanese]. Shiogama, Japan: Author

[2] National Institute for Educational Policy Research of Japan. (2006) TheBasic Documents on the Community Centre [Kominkan Ni Kansuru Kiso Shiryo, in Japanese].
In The Vice Minister of Education Japan in 1946. The Ultimatum No.122. Tokyo, Japan: Author

[3] NPO-Minatoshiogama. (2004). A History of Port Shiogama City [Shiogama Minato Mukashibanashi, in Japanese]. Shiogama, Japan: Author

[4] The Board of Education of Municipality of Shiogama. (1975). The History of Shiogama [Shiogama No Rekishi, in Japanese]. Shiogama, Japan: Author

[5] The Board of Education of Municipality of Shiogama. (2012). Handbook of the Education Centre of Shiogama 2012 [Shiogamashi Shogai Gakusyu Centre Youran (2012), in Japanese]. Shiogama, Japan: Author

[6] The Community Centre of Shiogama (1958). In The Handbook of the Community Centre of Shiogama [Shiogamashi Kominakn Yoran, in Japanese]. Shiogama, Japan: Author

[7] The Community Magazine of Shiogama. (2012). Fureaiesupu Shiogama_Kominkandayori, No.160 [Fureai Esupu Shiogama_Kominkan Dayori No.160 in Japanese]. Shiogama, Japan: Author

[8] The Compilation Committee of Shiogama's History (1986). The History of Shiogama City II [Shiogamashishi II Honapen II, in Japanese]. Shiogama, Japan: Author

[9] The History of Port City Shiogama and Shiogama Shrine [Shiogama Jinjjya To Minatomachi Shiogama No Rekishi, in Japanese]. (2003). In the Second Report of the Shiogama Study. Shiogama, Japan

[10] The Municipality of Shiogama. (n.d). An Architectural Feature of the Shiogama Community Centre [Shiogamashi Kominkan Bunkan No Kenchiku NoTokucho Ni Tsuite, in Japanese]. In An administrative document of Shiogama, Shiogama, Japan: Author

[11] The Nara Document on Authenticity (1994). Nara Conference on Authenticity in Relation to the World Heritage Convention, Nara, Japan. Retrieved from http://www.japan-icomos.org/charters/nara.pdf

[12] The Union of Plywood Industry of Japan. (2008). The Report of Durability on the Plywood Building [Shuseizai Kenchikubutu No Taikyu Chosa Houkokusho, in Japanese], Tokyo, Japan: Author

[13] The Union of Plywood Industry of Japan. (2012). The Handbook of the Plywood Architecture [Shuseizai Kenchikubutsu Settkei No Tebiki, in Japanese], Tokyo, Taisei-Syuttpansha. Tokyo, Japan: Author

[14] The Union of Plywood Industry of Japan. (n.d.). Th History of Important Plywood Buildings [Kichona Rekishiteki Syuseizai Kenchikubutsu, in Japanese]. In a Pamphlet of the Union of Plywood Industry of Japan. Tokyo, Japan: Author 
[15] Yotusi, Ryouichi. (1976). A research on the locations of Plywood Mills in Japan [Honpou No Shyuseizai-Kougyo No Bunnpu Ni Kansuru Kento, in Japanese], In The Science Journal of the Tohoku Gakuin University, No.7.
[16] Seiichiro Watanabe, Former Director of the Community Centre interview in November 2012 by the author. 